\title{
PENGARUH PROFITABILITAS, UKURAN PERUSAHAAN, PERTUMBUHAN PERUSAHAAN DAN KEBIJAKAN DEVIDEN TERHADAP KEBIJAKAN LEVERAGE PADA PERUSAHAAN MANUFAKTUR YANG TERCATAT DI BEI 2006 - 2010
}

\author{
Wikan Budi Utami \\ STIE AAS Surakarta \\ Email :wikan.budi@gmail.com
}

\begin{abstract}
ABSTRAK
Tujuan dari penelitian ini adalah untuk mengetahui pengaruh profitabilitas, ukuran perusahaan, pertumbuhan perusahaan dan kebijakan deviden terhadap kebijakan leverage pada perusahaan manufaktur yang tercatat di BEI tahun 2006-2010. Penelitian ini menggunakan purposive sampling pada perusahaan manufaktur yang tercatat di BEI tahun 2006-2010, dan diperoleh sebanyak 20 perusahaan manufaktur.

Alat analisis yang digunakan adalah regresi linear berganda, dimana diperoleh hasil variabel profitabilitas dan variabel kebijakan deviden berpengaruh signifikan terhadap kebijakan leverage sedangkan variabel ukuran perusahaan dan variabel pertumbuhan perusahaan tidak signifikan.

Koefisien determinasi $\left(\mathrm{R}^{2}\right)$ dalam penelitian ini sebesar $26,1 \%$ artinya bahwa semua variabel (profitabilitas, ukuran perusahaan, pertumbuhan perusahaan dan kebijakan deviden) mampu menjelaskan variasi kebijakan leverage sebesar 26,1\% sedangkan sisanya sebesar 73,9\% dijelaskan faktor lain yang tidak masuk dalam penelitian ini.

Kata kunci: profitabilitas, ukuran perusahaan, pertumbuhan perusahaan, kebijakan deviden dan kebijakan leverage.
\end{abstract}




\section{PENDAHULUAN}

\section{a. Latar Belakang Masalah}

Dalam perusahaan struktur pendanaan mengindikasikan bagaimana perusahaan membiayai kegiatan operasionalnya atau bagaimana perusahaan membiayai aktivanya. Perusahaan memerlukan dana yang berasal modal sendiri ataukah dipenuhi dengan modal asing.

Struktur

finansial

mencerminkan pula perimbangan antara keseluruhan modal asing (baik jangka pendek maupun jangka panjang) dengan jumlah modal sendiri”.

Tujuan yang akan dicapai dari penelitian ini adalah:

(1) Untuk mengetahui pengaruh profitabilitas terhadap kebijakan leverage.

(2) Untuk mengetahui pengaruh ukuran perusahaan terhadap kebijakan leverage.

(3) Untuk mengetahui pengaruh pertumbuhan perusahaan terhadap kebijakan leverage.

(4) Untuk mengetahui pengaruh kebijakan deviden terhadap kebijakan leverage.

\section{TINJAUAN PUSTAKA}

\section{a. Landasan Teori}

Pecking order theory sebagai salah satu teori tentang struktur modal, pertama kali dikemukakan oleh Myers (1984). Teori ini menjelaskan bahwa perusahaan melakukan keputusan leverage secara hirarki dari leverage internal dan eksternal
Agency theory yang Meckling (1976), teori ini relevan untuk menjelaskan struktur modal perusahaan. Jensen dan Meckling mengemukakan bahwa terjadi agency conflict antara manager, pemegang saham dan kreditur karena adanya perbedaan kepentingan diantara mereka. Munculnya agency conflict karena adanya benturan yang terjadi tersebut dapat menyebabkan adanya biaya yang disebut agency cost.

\section{Profitabilitas}

Profitabilitas perusahaan diindikasikan sebagai earnings (laba). Menurut Gitman (2003) "Profitability is the relationship between revenues and costs generated by using thr firm's assets - both current and fixed - in productive activities"

\section{Ukuran Perusahaan}

Ukuran perusahaan merupakan posisi perusahaan dalam industri, yang ditunjukkan dengan besarnya aktiva, tingkat penjualan dan maturitas perusahaan.

\section{Pertumbuhan Perusahaan}

Pertumbuhan perusahaan merupakan kemampuan perusahaan untuk meningkatkan size (Kallapur dan Trombley, 2001). Perusahaan dengan tingkat pertumbuhan yang tinggi memerlukan dana yang besar untuk lebih mengembangkan usahanya

\section{Kebijakan Deviden}

Kebijakan deviden menyangkut keputusan untuk membagikan laba atau 
menahannya guna diinvestasikan kembali dalam perusahaan (Weston and Brigham. 1994).

\section{Kebijakan Leverage}

Menurut Weston and Copeland (1996) menyatakan "Strukutur keuangan adalah cara bagaimana perusahaan membiayai aktivanya. Struktur keuangan dapat dilihat pada seluruh sisi kanan dari neraca. Ini terdiri dari hutang jangka pendek, hutang jangka panjang dan modal pemegang saham.

\section{b. Penelitian Terdahulu}

Penelitian tentang struktur pendanaan perusahaan atau debt policy telah banyak dilakukan, antara lain:

1. "Perilaku leverage perusahaan ditinjau dari dua teori yaitu, trade off theory dan pecking order theory" oleh Wijaya (2001). Penelitian ini memfokuskan pada konsistensi perilaku leverage, apakah sesuai dengan prediksi kedua teori tersebut, dengan cara membandingkan pengaruh dari pecking order theory dan trade off theory terhadap leverage perusahaan. Trade off theory diproksikan dengan variabel free cash flow dan volatilitas pendapatan perusahaan, sedangkan untuk pecking order theory diproksikan dengan variabel profitabilitas dan kesempatan investasi. Hasil yang diperoleh yaitu, free cash flow dan volatilitas pendapatan perusahaan menujukkan ambiguitas dalam menjelaskan perilaku leverage perusahaan, sedangkan profitabilitas berpengaruh secara signifikan terhadap leverage perusahaan, dan kesempatan investasi tidak berpengaruh secara signifikan. Sehingga dapat diambil kesimpulan bahwa pecking order theory lebih bisa menjelaskan perilaku leverage dibandingkan dengan trade off theory.

2. "Faktor-faktor yang Mempengaruhi Keputusan Pendanaan dari Hutang jangka Panjang, Total Hutang dan Ekuitas Perusahaan" oleh Susilawati (2004). Hasil penelitian ini menunjukkan bahwa struktur aktiva, profitabilitas dan struktur kepemilikan secara simultan mempengaruhi secara signifikan keputusan pendanaan dari hutang jangka panjang, total hutang dan ekuitas perusahaan manufaktur.

3. "Pengaruh karakteristik aktiva, ukuran, pertumbuhan, profitabilitas, financial constraint, dan struktur kepemilikan terhadap kebijakan hutang perusahaan manufaktur di Indonesia" oleh Agesti (2006). Hasil dari penelitian ini menyatakan bahwa karakteristik aktiva, ukuran perusahaan, dan kepemilikan managerial berpengaruh signifikan terhadap kebijakan hutang perusahaan, sedangkan variabel tingkat pertumbuhan, profitabilitas, financial constraint, dan kepemilikan institusional 
berpengaruh negatif terhadap kebijakan hutang.

c. Kerangka Pemikiran

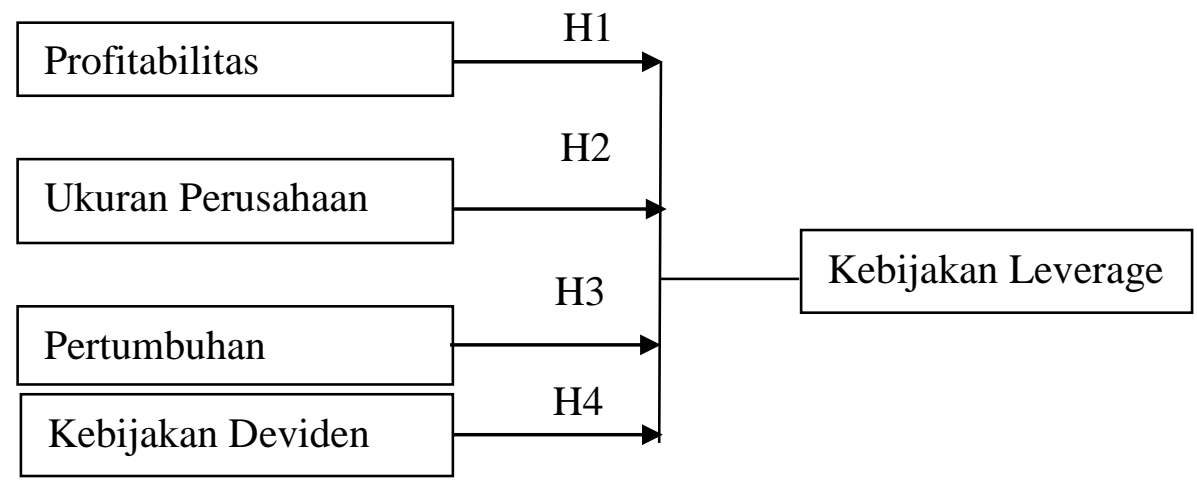

\section{d. Perumusan Hipotesis}

Adapun perumusan masalah adalah sebagai berikut:

H1 :Profitabilitas berpengaruh negatif signifikan terhadap kebijakan leverage perusahaan

$\mathrm{H} 2$ : Ukuran perusahaan berpengaruh positif signifikan terhadap kebijakan leverage perusahaan

H3 :Tingkat pertumbuhan perusahaan berpengaruh positif signifikan terhadap kebijakan leverage perusahaan

H4 : Kebijakan Deviden berpengaruh positif terhadap kebijakan leverage perusahaan

\section{METODE PENELITIAN}

\section{a. Populasi}

Populasi dalam penelitian adalah semua perusahaan manufaktur yang tercatat di Bursa Efek Indonesia pada tahun 2006-2010. Perusahaan manufaktur yang tercatat di BEI dipilih dengan alasan perusahaan-perusahaan manufaktur lebih banyak mempunyai pengaruh atau dampak terhadap lingkungan di sekitarnya sebagai akibat dari aktivitas yang dilakukan perusahaan.

b. Sampling

Pemilihan sample penelitian menggunakan teknik purpose sampling, dengan kriteria sebagai berikut:

1. Perusahaan manufaktur yang tercatat di Bursa Efek Indonesia dan dimuat dalam ICMD selama periode penelitian sesuaikan (2006-2010);

2. Perusahaan sample menerbitkan laporan keuangan selama 5 tahun berturut-turut;

3. Memiliki data lengkap yang dibutuhkan dalam penelitian ini.

\section{c. Jenis dan Sumber Data}

Jenis data yang digunakan dalam penelitian ini merupakan data sekunder yaitu data kuantitatif, yang disediakan oleh BEI dimana data tersebut adalah 
data yang sudah diolah. Sehingga peneliti dapat langsung memakainya. Adapun data tersebut meliputi : profitabilitas, ukuran perusahaan, pertumbuhan perusahaan, kebijakan deviden dan kebijakan leverage perusahaan-perusahaan manufaktur yang tercatat di BEI periode 20062010. Sumber datanya berupa laporan tahunan (annual report) perusahaanperusahaan manufaktur yang telah tercatat di Bursa Efek Indonesia periode 2006 - 2010 dan IDX statistic 2006 - 2010.

\section{d. Definisi Operasional Variabel}

Penelitian Dan Pengukurannya

1. Variabel Dependen

Kebijakan leverage sebagai variabel dependen, yang diproksikan dengan menggunakan Debt to Asset Ratio ( DAR ).

$$
D A R=\frac{\text { Total_Debt }}{\text { Total_Asset }} x 100 \%
$$

Ukuran perusahaan dapat dihitung dengan rumus sebagai berikut:

Ukuran perusahaan : log (total asset)

c) Pertumbuhan Perusahaan

Variabel ini diukur dengan ratio market to book ratio (MBR).

$M B R=$ market_value_of_equity $(M V E)+\frac{\text { Total_Debt }}{\text { Total_Asset }}$

MVE = harga penutupan $\times$ jumlah lembar saham yang beredar

\section{d) Kebijakan Deviden}

Dalam penelitian ini, ratio yang dipakai untuk mengukur kebijakan deviden adalah deviden payout ratio diukur dengan membandingkan antara total deviden dengan total laba bersih.

$$
D P R=\frac{\text { Total } \_ \text {Deviden }}{\text { Total_Laba_Bersih }} x_{-} 100 \%
$$

2. Variabel Independen

a) Profitabilitas

Profitabilitas menurut

Weston dan Brigham (2002) adalah hasil bersih dari serangkaian kebijakan dan keputusan.

$$
R O A=\frac{\text { Net_Income }}{\text { Total_Asset }} \times 100 \%
$$

\section{b) Ukuran Perusahaan}

e. Metode Analisis

1. Uji Data

a. Uji Normalitas

Untuk menguji normalitas data, dapat menggunakan uji Kolmogorov Smirnov.

b. Uji Autokorelasi

Untuk mendeteksi ada tidaknya autokorelasi dapat dilakukan dengan uji Durbin Watson (DW test).

c. Uji Heteroskedastisitas 
Untuk mendeteksi ada tidaknya heteroskedastisitas dapat dilakukan dengan uji Glejser.

d. Uji Multikolinieritas Untuk mendeteksi adanya multikolinieritas dengan melihat nilai Variance Inflation Factors (VIF).

2. Uji Hipotesis

a. Model Persamaan Regresi Linear Berganda

Analisa regresi digunakan untuk menunjukkan seberapa jauh pengaruh variabel independen terhadap variabel dependen.

$$
\mathrm{DEBT}=\alpha+\beta 1 \mathrm{ROA}+\beta 2
$$

$\mathrm{SIZE}+\beta 3 \mathrm{MBR}+\beta 4 \mathrm{DPR}+\mathrm{e}$

Keterangan :

DEBT : hutang perusahaan

ROA : return on asset

SIZE : ukuran perusahaan

MBR : market to book ratio
DPR : deviden payout ratio

e : distrubance error

b. Uji Hipotesis dengan Uji " $t$ " Hipotesis ini diuji dengan uji-t dengan taraf signifikan sebesar $\alpha=5 \%$.

c. Uji Hipotesis dengan Uji $F$ Nilai F digunakan untuk mengetahui kesesuaian variabel independen untuk memprediksi variabel dependen.

d. Koefisien Determinasi $\left(\mathrm{R}^{2}\right)$ Koefisien determinasi $\left(\mathrm{R}^{2}\right)$ mengukur kecocokan dengan data yang ada (goodness of fit) dari persamaan regresi yang dicerminkan oleh proporsi atau presentase variasi total dalam variabel dependen, yang dijelaskan oleh variabel independen (Gujarati, 1995).

\section{ANALISIS DATA DAN PEMBAHASAN}

a. Analisis Data

1. Uji Asumsi Klasik

a. Uji Normalitas

Tabel 4.2

Hasil Uji Normalitas dengan Uji Kolmogorov Smirnov

\begin{tabular}{|l|c|}
\hline & Unstandardized Residual \\
\hline Asymp. Sig. (2-tailed) & 0.329 \\
\hline
\end{tabular}

1) Test distribution is normal

2) Calculated from data

Sumber : Data sekunder diolah (2011) 
Pengaruh Profitabilitas, Ukuran Perusahaan, Pertumbuhan Perusahaan

Dan Kebijakan Deviden Terhadap Kebijakan Leverage Pada Perusahaan

Manufaktur Yang Tercatat Di BEI 2006 - 2010

a. Uji Autokolerasi

Tabel 4.3

Hasil Uji Durbin Watson

\begin{tabular}{|c|c|}
\hline Model & Durbin-Watson \\
\hline 1 & 1.639 \\
\hline
\end{tabular}

a. Predictors: (Constant), Profitabilitas, Ukuran Perusahaan, Pertumbuhan, Kebijakan Deviden

b. Dependent Variabel : Leverage

Sumber : Data sekunder diolah (2011)

Dari hasil uji DW diketahui

hasil Durbin Watson sebesar

1.639 maka Ho diterima dan $\mathrm{Ha}$ ditolak, sehingga tidak terdapat auto korelasi baik positif maupun negatif.

c. Uji Heteroskedastisitas

Tabel 4.4

Hasil Uji Heteroskedastisitas

Correlations

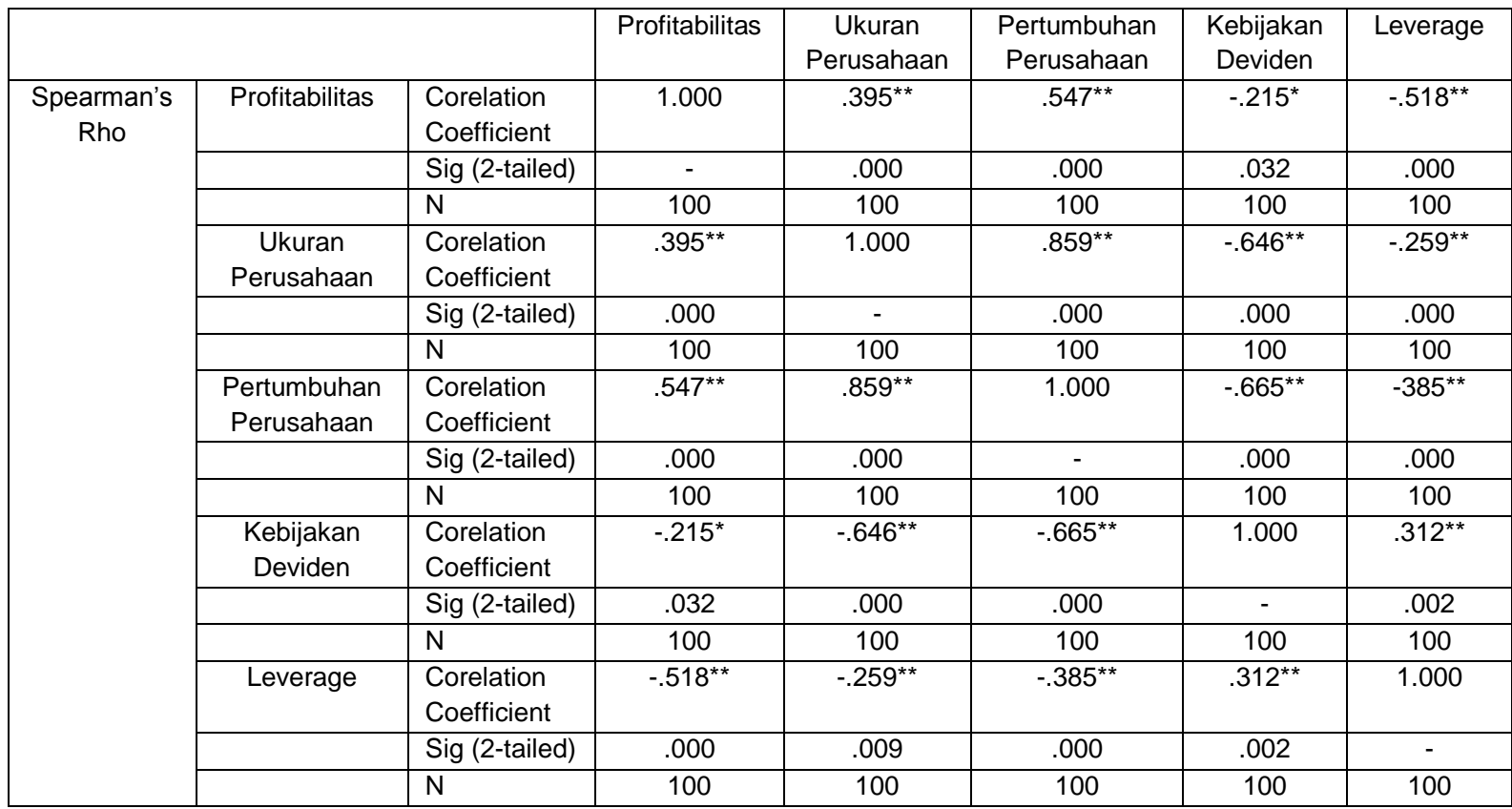

${ }^{* *}$ Corelation is significant at the 0.01 level (2-tailed).

${ }^{*}$ Corelation is significant at the 0.01 level (2-tailed).

Sumber : output SPSS (data sekunder diolah, 2011)

Dari hasil uji Spearmen

Rank Corelation semua variabel

bebas mempunyai nilai

signifikasi yang lebih kecil dibandingkan dengan alfa sebesar 0.05 sehingga dapat disimpulkan bahwa dalam model diatas tidak terjadi gejala heteroskedastisitas. 
d. Uji Multikolinieritas

Tabel 4.5

Hasil Uji Multikolinearitas

\begin{tabular}{|c|c|c|c|}
\hline \multirow{2}{*}{ Model } & \multicolumn{2}{c|}{ Collinearity Statistics } \\
\cline { 3 - 4 } & & Tolerance & VIF \\
\hline \multirow{3}{*}{1} & Profitabilitas & 0.880 & 1.136 \\
\cline { 3 - 4 } & Ukuran Perusahaan & 0.594 & 1.684 \\
\cline { 2 - 4 } & Pertumbuhan Perusahaan & 0.670 & 1.492 \\
\cline { 2 - 4 } & Kebijakan Deviden & 0.792 & 1.262 \\
\hline
\end{tabular}

a. Dependent Variable : Leverage

Sumber : output SPSS (data sekunder diolah, 2011)

Dari hasil uji multikolinearitas

diperoleh nilai VIF lebih kecil dari 10 dan nilai tolerance lebih besar dari 0,1 sehingga dapat dikatakan model tersebut tidak terdapat multikolinieritas antar variabel bebas.

\section{Uji Hipotesis}

a. Persamaan Regresi Linear Berganda

\section{Tabel 4.6}

Hasil Uji Regresi Linear

\begin{tabular}{|l|l|c|}
\hline \multirow{2}{*}{ Model } & \multicolumn{2}{c}{ Coefficients } \\
\hline \multirow{3}{*}{1} & $\begin{array}{c}\text { Unstandardized } \\
\text { Coefficients }\end{array}$ \\
\cline { 3 - 3 } & (Constant) & B \\
\cline { 2 - 3 } & Profitabilitas & .502 \\
\cline { 2 - 3 } & Ukuran Perush & -.791 \\
\cline { 2 - 3 } & Pertumbuhan & .007 \\
\cline { 2 - 3 } & Kebijakan Deviden & 5.81772858 \\
\hline
\end{tabular}

a. Dependen Variable : Leverage

Sumber :output SPSS (data sekunder diolah, 2011)

Berdasarkan hasil regresinya menjadi sebagai perhitungan SPSS persamaan berikut:

$$
\text { Lev }=0.502-0.791 \text { Pro }+0.007 \log \text { Size }+5.8177 \text { Gro +7.950Dev }
$$

Dari hasil analisis dapat diketahui bahwa variabel bebas yang berpengaruh positif terhadap leverage adalah profitability dengan koefisien sebesar 0,791. Hasil ini menunjukkan bahawa semakin besar nilai profitabilitas maka 
semakin kecil leverage, sebaliknya jika nilai profitability semakin kecil, leverage cenderung meningkat. Nilai ukuran perusahaan, pertumbuhan perusahaan dan kebijakan deviden memberikan pengaruh positif terhadap kebijakan leverage, yang berarti meningkatnya ukuran perusahaan, pertumbuhan perusahaan dan kebijakan deviden mengakibatkan meningkatnya kebijakan leverage.

Tabel 4.7

Hasil Uji Partial

Coeficients

\begin{tabular}{|l|l|c|c|}
\hline \multicolumn{2}{|l|}{ Model } & $t$ & Sig \\
\hline \multirow{3}{*}{1} & Profitabilitas & -5.269 & .000 \\
\cline { 2 - 4 } & Ukuran Perush & .247 & .805 \\
\cline { 2 - 4 } & Pertumbuhan & .772 & .442 \\
\cline { 2 - 4 } & Kebijakan Deviden & 2.828 & .006 \\
\hline
\end{tabular}

a. Dependen Variabel : Leverage

Sumber : output SPSS (data sekunder diolah, 2011)

Dari table 4.7 diatas diketahui besarnya pengaruh masing-masing variabel independen terhadap variabel dependen adalah sebagai berikut : 1. Profitabilitas terhadap

\section{Leverage}

Hasil penelitian diperoleh nilai signifikansi sebesar 0,000 $(<0.05)$, maka disimpulkan bahwa hipotesis pertama (H1) yang berbunyi "Profitabilitas berpengaruh negatif signifikan terhadap kebijakan leverage" perusahaan manufaktur di Bursa Efek Indonesia periode 2006 2010" adalah diterima.
2. Ukuran Perusahaan

Terhadap Leverage

Dari tabel 4.6 diketahui $\mathrm{t}$ hitung ukuran perusahaan $\left(\mathrm{X}_{2}\right)$ terhadap leverage (Y) sebesar 0.247 atau sebesar $24,7 \%$ dan signifikansi untuk variabel ukuran perusahaan sebesar 0,805 , maka disimpulkan bahwa hipotesis kedeua (H2) yang berbunyi "Ukuran perusahaan berpengaruh positif signifikan terhadap kebijakan leverage" perusahaan manufaktur di Bursa Efek Indonesia periode 2006 2010" adalah ditolak. 
3. Pertumbuhan Terhadap

\section{Leverage}

Dari tabel 4.6 diketahui $t$ hitung ukuran perusahaan $\left(\mathrm{X}_{3}\right)$ terhadap leverage (Y) sebesar 0.772 atau sebesar $77,2 \%$ dan signifikansi untuk variabel ukuran perusahaan sebesar 0,442 $(>0.05)$, maka disimpulkan bahwa hipotesis ketiga (H3) yang berbunyi "Pertumbuhan perusahaan berpengaruh positif signifikan terhadap kebijakan leverage perusahaan manufaktur di Bursa Efek Indonesia periode 2006 - 2010" adalah ditolak.
4. Kebijakan Deviden

Terhadap Leverage

Dari tabel 4.6 diketahui $\mathrm{t}$ hitung kebijakan deviden $\left(\mathrm{X}_{4}\right)$ terhadap leverage (Y) sebesar 2,828 atau sebesar $282,8 \%$ dan signifikansi untuk variabel kebijakan deviden sebesar 0,006 (< 0.05), maka disimpulkan bahwa hipotesis keempat (H4) yang berbunyi "Kebijakan deviden berpengaruh positif terhadap kebijakan leverage perusahaan manufaktur di Bursa Efek Indonesia periode 2006 2010 " adalah diterima.

\section{c. Uji F}

Tabel 4.8

Hasil Uji F

ANOVA

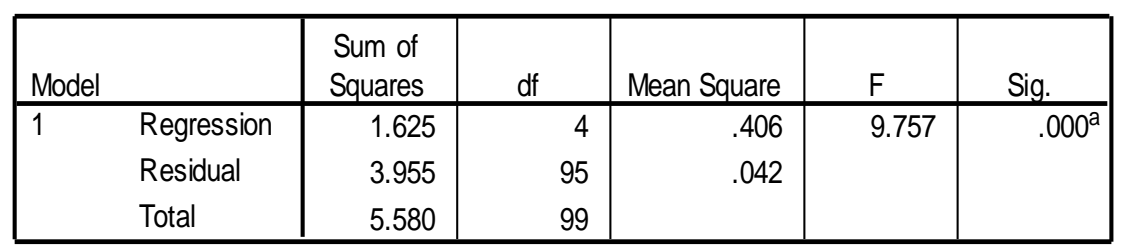

a. Predictors: (Constant), Kebijakan Deviden, Prof itabilitas, Pertumbuhan, Ukuran $P$

b. Dependent Variable: Laverage

Sumber : output SPSS (data sekunder diolah, 2011)

Berdasarkan tabel 4.8, diperoleh nilai $\mathrm{F}$ hitung 9,757 dan signifikansi sebesar 0,000 yang lebih kecil dari 0,05 . Hal ini berarti Profitabilitas $\left(\mathrm{X}_{1}\right)$, Ukuran Perusahaan $\left(\mathrm{X}_{2}\right)$, Pertumbuhan
Perusahaan $\left(\mathrm{X}_{3}\right)$ dan Kebijakan Deviden $\left(\mathrm{X}_{4}\right)$ sebagai variabel independen terdapat kesesuaian dengan variabel dependennya (Leverage). 
Pengaruh Profitabilitas, Ukuran Perusahaan, Pertumbuhan Perusahaan

Dan Kebijakan Deviden Terhadap Kebijakan Leverage Pada Perusahaan

Manufaktur Yang Tercatat Di BEI 2006 - 2010

d. Koefisien Determinasi

Tabel 4.9

Koefisien Determinasi

\begin{tabular}{|c|c|c|c|c|}
\multicolumn{5}{|c|}{ Model Summary } \\
\hline Model & $\mathrm{R}$ & $\mathrm{R}$ Square & $\begin{array}{c}\text { Adjusted } \mathrm{R} \\
\text { Square }\end{array}$ & $\begin{array}{c}\text { Std Error of the } \\
\text { Estemate }\end{array}$ \\
\hline 1 & $540^{\mathrm{a}}$ & .291 & .261 & .20404733 \\
\hline
\end{tabular}

a. Predictor: (Constant), Profitabilitas, Ukuran Persh, Pertumbuhan, Kebijakan Deviden

b. Dependent Variabel : Leverage

Sumber : output SPSS (data sekunder diolah, 2011)

Dari Tabel 4.9 dapat diketahui nilai Adjusted $\mathrm{R}^{2}$ sebesar 0,261 nilai ini menunjukkan bahwa Profitabilitas $\left(\mathrm{X}_{1}\right), \quad$ Ukuran Perusahaan $\left(\mathrm{X}_{2}\right)$, Pertumbuhan Perusahaan $\left(\mathrm{X}_{3}\right)$ dan Kebijakan Deviden $\left(\mathrm{X}_{4}\right)$ dapat menjelaskan variabel Kebijakan Leverage $(\mathrm{Y})$ perusahaan manufaktur yang tercatat di BEI periode 2006 2010 sebesar $26,1 \%$, sedangkan sisanya sebesar $73,9 \%$ dijelaskan oleh variabel lain yang tidak diperhitungkan dalam penelitian ini.

\section{KESIMPULAN DAN SARAN}

a. Kesimpulan

1. Profitabilitas (ROA) memiliki pengaruh negatif terhadap kebijakan leverage pada perusahaan manufaktur yang tercatat di BEI tahun 2006 2010.

2. Ukuran perusahaan tidak berpengaruh terhadap kebijakan leverage pada perusahaan manufaktur yang tercatat di BEI tahun 2006 - 2010.
3. Pertumbuhan perusahaan tidak berpengaruh terhadap kebijakan leverage pada perusahaan manufaktur yang tercatat di BEI tahun 2006 - 2010.

4. Kebijakan deviden berpengaruh positif terhadap kebijakan leverage pada perusahaan manufaktur yang tercatat di BEI tahun 2006 - 2010.

b. Saran

Berdasarkan hasil -hasil penelitian diatas, beberapa saran yang perlu diperhatikan dalam penelitian ini antara lain:

1. Bagi manajer keuangan perlu memperhatikan beberapa variabel yang berpengaruh signifikan terhadap kebijakan leverage, dalam hal ini variabel profitabilitas dan kebijakan deviden. Adapun langkah yang bisa dilakukan adalah dengan berusaha meningkatkan perolehan profitabilitas dengan meningkatkan pendapatan dan mempertahankan biaya atau mempertahankan pendapatan dan mengurangi biaya. Dari hasil penelitian diperoleh nilai rata- 
rata sebesar $0.521 \%$, dimana banyak perusahaan yang membayarkan deviden, walaupun dengan prosentasi yang kecil, hal ini dikarenakan laba yang diperoleh perusahaan sebagian besar dipergunakan untuk pemenuhan pendanaan perusahaan.

2. Bagi investor dapat memberikan gambaran mengenai kondisi perusahaan pada saat akan melakukan investasi pada perusahaan tertentu, sehingga mendapatkan informasi yang lebih banyak mengenai karakteristik perusahaan yang dimaksud. Dengan proporsi hutang yang cukup tinggi, maka resiko juga semakin tinggi dimana perusahaan akan mengutamakan pembayaran bunga maupun pokok hutang. Dengan semakin tinggi hutang suatu perusahaan maka kewajiban suatu perusahaan terhadap kredit juga semakin tinggi. Sehingga kemampuan perusahaan untuk melakukan pembayaran deviden semakin kecil.

3. Bagi kreditur dengan berpatokan pada 5C (character, capacity, capital, collateral, condition of economy) sebagai langkah meminimalisir terjadinya resiko. Dari penelitian ini diperoleh nilai rata-rata DAR perusahaan manufaktur adalah sebesar $54.20 \%$, hasil tersebut kurang bagus. Semakin tinggi DAR semakin besar debt (hutang) yang dimiliki perusahaan dibandingkan besar asset yang dimiliki. Kreditur dalam memberikan kredit harus mempertimbangkan resiko pasar dan resiko perusahaan. Terkait dengan resiko perusahaan, kredit harus menghitung besar asset dan jumlah hutang yang dimiliki sehingga besarnya kredit sesuai dengan kebutuhan agar perusahaan tidak menanggung beban bunga yang melebihi kemampuannya.

4. Bagi peneliti selanjutnya dapat memperbanyak sampel dengan memperluas jenis perusahaan dan memperpanjang tahun penelitian serta penambahan variabelvariabel lain, antara lain: kepemilikan manajerial, kepemilikan institusional, tingkat suku bunga, inflasi, dan tingkat pajak.

\section{DAFTAR PUSTAKA}

Abel, E.E. (2008), Firm Size and corporate financial-leverage choice in a developing economy, Evidence From Nigeria, The Journal of Risk Finance, Vol. 9, pp. 351-364.

Agesti, Kumala, (2006), Pengaruh Karakteristik Aktiva, Ukuran, Pertumbuhan, Profitabilitas, Financial Constraint, dan Struktur Kepemilikan terhadap Kebijakan Hutang Perusahaan Manufaktur di Indonesia, Tesis S2, STIE YKPN, Yogyakarta. 
Ang, J.S.(1992), On the theory of finance for privately held firms, The Journal of small Business finance, Vol. 1, pp. 185-203.

Atkeson, Andrew.(2005), A Dynamic Theory of Optimal Capital Structure and Executive Compensation, Research Memo, University of California, Los Angeles.

Barclay, M.J., Smith, C., and Watts, R., (1995), "The Determinants of corporate leverage and devidend policies, Journal of Applied Corporate Finance, Vol. 7, pp. 4-19.

Barton, S.L., Hill, N.C., and Sundaram, S. (1989), An empirical test of stakeholder theory predictions of capital structure, Financial Management, Vol. 18, pp. 36-44.

Boodhoo, R., (2009), Capital Structure and Ownership Structure: A Review of Literature, Journal of Online Education, New York, January 2009.

Brigham, Eugene F., and Joel F. Houston, (2001) Fundamentals of Financial Management, Alih Bahasa Dodo Suharto dan Herman Wibowo, Manajemen Keuangan, Edisi Kedelapan, Buku Satu, Erlangga, Jakarta.

, (2001), Fundamental of Financial Management, Alih Bahasa Dodo Suharto dan Herman Wibowo,
Manajemen Keuangan, Edisi Kedelapan, Buku Dua, Erlangga, Jakarta.

Brigham, Eugene F., and Phillip R. Daves, (2004), Intermediate Financial Management, Eight Edition, South Western, United States.

Chung, K.H. (1993), Asset characteristiesand corporate debt policy: an empirical test, Journal of Business Finance and Accounting, Vol.20, pp 83-98.

Cooley, T.F. and Quandrini, V. (2001), Financial markets and firm dynamics, The American Economic Review, Vol. 91, pp. 286-310.

Crutehley, C.E. and Hansen, R.S. (1989), A test of the agency theory of managerial ownership, corporate leverage, and corporate devidends, Financial Management, Vol. 4, pp. 36-46.

Darmoko, Edi Totot, (2007), Pengaruh Kebijakan Deviden, Profitabilitas dan Fixed Asset Terhadap Kebijakan Hutang Berdasarkan Model Pecking Order, Tesis S2, Universitas Trisakti

Drobetz, Wolfgang., and Fix, Roger. (2003), Determinants of the Capital Structure/ Some Evidence for Switzerland, Working Paper, Departement of Finance, Vol. 4, pp. 70-80.

Fama, E. and French, K., (2002), Testing tradeoff and pecking order predictions about dividends and debt, Review of Financial Studies, Vol. 1, pp 1-33. 
Frank, Murray Z., and Vidhan K Goyal. (2003), Testing the pecking order theory of capital structure, Journal of Financial Econimics, Vol. 16, pp. 7080.

Frank, Murray Z., and Vidhan K Goyal. (2003), Capital Structure Decision, www.afajof.org

Frank, M. Z., and Vidhan K.G. (2005), Tradeoff And Pecking Order Theories Of Deb, Working Paper Series.

Gaver, J.J. and Gaver, K.M. (1993), Additional evidence on the association between the invesment opportunity set and corporate financing, dividend, and compensation policies, Journal of Accounting and Economics, Vol. 16, pp. 125-60.

Ghosh, A., Chai, F., and Li, W., (2000), The Determinants of Capital Structure, American Business Review, Vol. 18, No. 129

Ghozali, Imam, (2001), Aplikasi Analisis Multivariative dengan Program SPSS, BP-UNDIP, Semarang

Gitman, Lawrence J., (2003), Principles of Managerial Finance, Tenth Edition, Pearson Education, Inc., United State.

Gujarati, D.N. (2006), Dasar-Dasar Ekonometrika, Erlangga 